\title{
Coworking and design: a social innovation case study
}

\author{
Gheysa Caroline Prado ${ }^{1, a}$, Alexandre Vieira Pelegrini ${ }^{2}$ and Liliane Iten Chaves ${ }^{3}$ \\ ${ }^{1}$ Federal University of Parana (UFPR) Tuiuti University of Parana (UTP), PPGDesign, gheysa.p@gmail.com \\ ${ }^{2}$ Federal University of Technology - Parana, PPGDesign, avpelegrini@gmail.com \\ ${ }^{2}$ Fluminense Federal University, PPGDesign, lilianeitenchaves@id.uff.br
}

\begin{abstract}
The shared workspaces, known as coworking, are part of a recent urban happening and still understuddied. The present article used ways and tools aiming to identify a social innovation promising case in the field of coworking spaces in Curitiba (Brazil) as. Solimões 541 was identified and the goal was to study it according to Mazini (2008)'s proposed framework. The results confirmed the case as a social innovation initiative and the discussion points to the need of more similar coworking spaces.
\end{abstract}

Keywords. coworking, design, social innovation.

\section{Introduction}

The population growth, the consequent increase in urbanization and globalization and the economic, financial and migration crisis of the last decades are changing the role of designer and its ways of working. From the sustainability perspective, for along time, the designers have been seen more as part of the problem than the solution. Nonetheless, in academia and also outside, there are studies and movements seeking innovative, creative and collaborative solutions for daily problems that can drive towards more environmental, social and economic sustainable behaviors (MANZINI, 2008; KOTZ, 2009). These solutions are being studied within the design field and, filling some requirements, are called Social Innovation by Manzini (2008).

This article describes the use of ways and tools in order to identify a promising social innovation case in the field of coworking spaces in Curitiba-PR (Brazil). It aims to study the case found to check if it fills the stages to be considered a social innovation according to Manzini (2008)'s framework.

The results confirm the Solimões 541 case as a social innovation initiative as it represents a new way of doing something offering environmental and social benefits; it also is replicable in different contexts.

The discussion suggests that there is an emergent need for more shared spaces, mainly due to the new ways of working and the development and propagation of the shared economy.

\section{Coworking}

From the 80 's, the spreading of globalization, and the 90 's, the popularization of the new ways of

\footnotetext{
${ }^{\mathrm{a}}$ Corresponding author: gheysa.p@gmail.com
}

communications and the digital media leveraged by the internet, knowledge economy emerges (HOSPERS, 2003). Meantime there was the exponential growth in population in urban areas, going from less tan $40 \%$ to more than $55 \%$ across the globe but, in some countries like Brazil, the proportion reached close to $75 \%$. The development of this new economy along with the accelerated urbanization process require the spaces to be reinvented, more specifically in the urban areas where there is larger concentration of diversity, knowledge, technology and innovation, the called creative cities (HOSPERS, 2003).

Due to all theses transformations, since the beginning of the $21^{\text {st }}$ Century, the work settings in most of the big cities around the world faced substantial change. Especially at the creative cities, not only the ways of work have changed, but also the workspaces and the organization structures (GANDINI, 2015).

To embrace these new patterns, the cities should broaden the opportunities for meetings, tacit knowledge exchange, enhancing idea generation and innovation among different professional fields, including social and cultural components individually inherent (JOHNSON, 2011; SCOTT, 2006).

The economic, financial and migration crisis of the last decades followed by the recession challenged the established knowledge economy increasing the need for innovation (OCDE, 2005; MARZANO, 2011) and enhancing shared economy concepts. As a result and seeking alternatives to continue working, several selfemployed professionals and small entrepreneurs found in coworking spaces a chance.

On this urban and globalized context, immersed in crisis and recession, the coworking spaces emerged, spread and developed. According to Gandini (2015), coworking spaces are different from the traditional workspaces headed by single companies or even 
different from the freelancers independent work at home or coffee shops. Ferguson (2014) states that its emergence is highly related with bottom up initiatives, like communal gardens and artistic interventions, which seek to re-appropriate the urban space through active and democratic engagement.

Besides being related to knowledge economy, shared economy and globalization phenomenon, the coworking spaces are what Hospers (2003) calls global-local paradox. It deals exactly with the apparent contradiction of increasing the importance and value of local aspects of the knowledge economy while globalization keeps expanding (HOSPERS, 2003).

Therefore, for the purpose of this article, coworking space refers to a workspace based on its own values and features, lined up with collaborative consumption practices encouraged by the shared economy (MERKEL, 2015). These values are (Table 1):

Table 1. Coworking spaces values.

\begin{tabular}{|c|c|}
\hline Value & Characteristics \\
\hline Openness & $\begin{array}{l}\text { transparency and openness of spaces and } \\
\text { ideas; }\end{array}$ \\
\hline Collaboration & $\begin{array}{l}\text { meeting and collaboration with all sorts of } \\
\text { people with all sorts of knowledge; }\end{array}$ \\
\hline Accessibility & $\begin{array}{l}\text { effort to be accessible to all, meaning } \\
\text { ideas and people, both financially and } \\
\text { physically; }\end{array}$ \\
\hline Community & connections and mutual support; \\
\hline Sustainability & $\begin{array}{l}\text { conscious and optimized use of spaces and } \\
\text { objects. }\end{array}$ \\
\hline
\end{tabular}

Font: The authors (adapted from MORISET, 2014 and MERKEL, 2015).

Schatzki et al. (2001, apud Merkel, 2015) state that being the coworking spaces a very recent concept, the engagement and user participation on the processes of knowing, doing and saying are part of the constant resignification of the space according to their own needs.

\section{Social Innovation}

Social innovation means any innovation able to offer improvement in everyday life. They are unconventional ways of think, act and problem solving daily problems in creative and collaborative ways seeking to enhance behaviour change towards environmental, social or economical sustainability. Most of the time these solutions emerge as bottom up initiatives as social innovation cases from creative communities (MANZINI, 2008). Manzini (2008) created a framework to study these initiatives and to check some characteristics in order to consider the solution and a social innovation one. The aim of the studies is to verify the possibility of replication of the case in different contexts.

These innovations can be found in many different ways, but it is possible to list some recurrent characteristics: they are local and small. The size of it is not one of Manzini (2008)'s requirements to be considered social innovation, nonetheless small groups tend to become more cohesive and socially engaged, increasing members sense of belonging (SCHUMACHER, 1981). Apart of the initiative's size, sustenance of local knowledge, different uses for existing technology establishing a virtuous cycle of sustainability are fundamental characteristics to consider it as a social innovation case (MANZINI, 2008).

The sustenance of local knowledge, its units and other aspects that hold it together, is a key concept of social innovation definition. According to Hall (2006) and Zaoual (20016) these characteristics are built over time on nationalities, religion, beliefs, ethnic etc. through symbolic, practical and social aspects without being fixed and unalterable. Recognizing and respecting these different cultural identities allow bottom up social innovation initiatives to thrive (ZAOUAL, 2006; MANZINI, 2008).

\section{Methods}

The present article describes the search and the study of a promising social innovation case in Curitiba-PR (Brazil). The collected cases are part of a Design Post Graduation Program subject at Federal University of Paraná (UFPR) in order to integrate a collection of cases to be analysed and compared in parallel with each other later.

The field of the case was chosen for being of interest for the authors, coworking spaces, and for representing a contemporaneous movement as an object of a case study (YIN, 2001).

For this research, the principles presented by Manzini (2008) for the identification of promising social innovation cases were used. These principles are drivers to indicate that a case can be relevant to DESIS Research Group. The identified case, Solimões 541, a coworking space in Curitiba-PR (Brazil) was submitted to the Manzini (2008)'s framework to verify if it was, in fact, a social innovation initiative. The framework checks the following characteristics:

1) presents a new way of organizing daily life;

2) offers social benefits;

3) offers environmental benefits; and

4 ) is replicable in other contexts.

The research strategy is of applied nature that aims to create practical knowledge to solve specific problems in local contexts. The data are qualitative due to its dynamic relation among object of study and the real world. Because of its exploratory characteristics, the authors used the case study technical procedures (YIN, 2001).

The triangulation of field data, secondary data and literature provided validity for the present study.

The guidelines defined by Design for Social Innovation and Sustainability (DESIS, 2015) - a network of design labs, based in design schools and designoriented universities, actively involved in promoting and 
supporting sustainable change - were used to collect the field data.

The subject dynamic starts with the presentation of social innovation and design for social innovation concepts followed by an invitation for the students to gather in small groups. The groups have to search and bring some local social innovation cases to present in class where the importance, relevance and compliance with Manzini's (2008) principles are discussed. For this stage the students use the Light format, document to get the main data about the case to be studied, secondary data is used for this phase. The purpose is to present the case in class for peer evaluation and discussion on the possibility of the gathered case to be a promising social innovation case.

After the cases have been discussed and approved by the peers each group progress to a deeper understand of the case. In order to do so, a visit followed by an interview are scheduled with the initiative coordinator. For the interview the following ways and tools predefined by DESIS network are used:

1-Interview Guide: aims to get information about the initiative origins, the users, its economical role and expectations. The questionnaire is open and semistructured in six parts: the genesis, the users, the answers, the initiative, the economy, the perspectives.

1)the genesis: tries to understand the motivations behind the initiative;

2)the users: seeks to draw the participants;

3)the answers: the interviewer tries to sense what are the answers seek by the coordinator through the initiative;

4)the initiative: has questions to gather a description for the initiative, understand how it works, its benefits for participants and the society as a whole;

5)the economy: seeks information about the costs, how they are absorbed by the initiative, payment details, profit etc.

6)the perspectives: checks what are the possible future scenarios for the initiative.

As a support tool for the interview there is the Photographic Observation to help identify elements pointed out during the interview, followed by a picture checklist.

Both the interview and the pictures are allowed by the use of another document template, the "Use of data consent".

After the interview and the photographic observation the students fill out the form "In-depth format Analysis" listing all the findings. The goal is to analyse the case according to the following: problematic background and context, main actors (promoters, supporters, users, connections), development, economic sustainability, Organisation, sustainable lifestyle, success and failure.

Also the photographs are sorted in another DESIS template, the Format_VisualisationTemplate.

Besides the DESIS tolls, the author also used coding for the analysis, classification and description of the field data collected in the results presented (MILES, HUBERMAN E SALDAÑA, 2013).

\section{Results}

The identification of the studied case started as subject proposition at UFPR Design Post Graduation Program Design and Social Innovation discipline. The Light Format was used as a first step for the process. The search for a promising social innovation case was focused on the coworking spaces in Curitiba-PR (Brazil) by the research interest of the authors. From this point, Solimões 541 initiative, an open house that worked on a self-funding and self-management system, was identified. Opened in 2014 it aimed to enable people and ideas spontaneous encountering, enabling the creation of new projects and possibilities. It was shaped inspired by similar initiatives in São Paulo, and offered workspaces, entertainment and collaboration spaces. By October, 2015, date of this study, housed 6 small companies and some liberal professionals. The companies and professionals were all related to creative industry - artist, theatre group, journalist etc. From the secondary data it was possible to create a moodboard (Figure 1) with images of the different uses of the place. Using the Light Format the authors identified other main characteristics of the place like its managers, address and information that enabled the case study to continue.

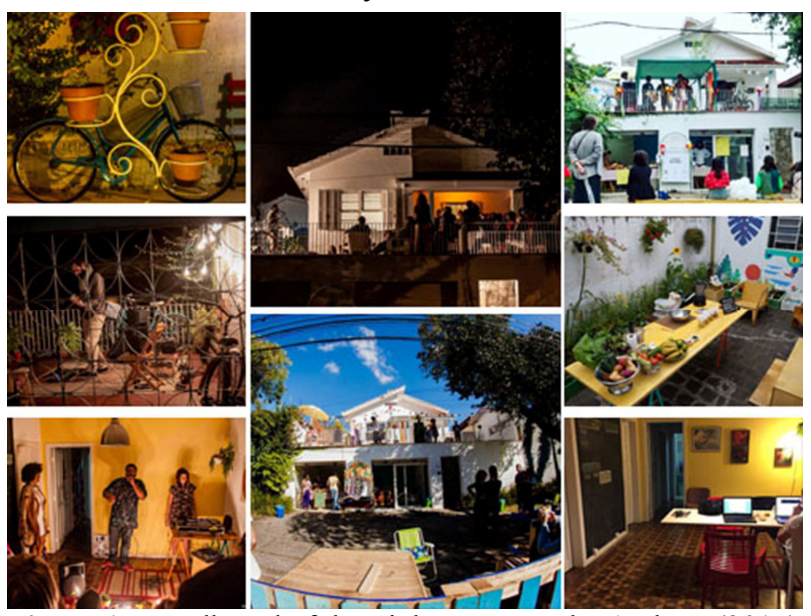

Figure 1. Moodboard of the Light Format. The Authors (2015)

After the filling of the Light Format with all the available information the place was visited to interview the manager and other participants and users. During the visiting time there were many simultaneous activities happening, like using of the external area for relaxation and entertainment, collaborative lunch preparation at the kitchen and a meeting for expanding the place's possible uses and ways of funding. Besides that, there was also ordinary office working taking place at some rooms.

The interview was made mostly with one of the users of the space, which, by the initiative's characteristic, has the same rights, and duties of all participants. The manager was there for the meeting previously mentioned and also was able to give more detailed information about the project background. He was the responsible for all the legal and financial hires for the place, as the house rent; internet, light and water companies bills. By then, he also was the one responsible to pay the difference between the money raised and the full invoice. The 
interview along with the secondary data revealed that there were 47 people who contributed in a monthly basis for the endurance of the project, which guaranteed around $75 \%$ of the income needs for the place to be selfsufficient. Besides the monthly subscribers, another way of raising money was though subletting for events on evenings and weekends and through a donation box. According to the founder and manager, these two later options should no be counted for the self-sufficiency but as a possibility to make extra money for other needs and future investments.

The interview allowed identifying characteristics of sustainability promotion, categorized in environmental, social and economic dimensions (Table 2), according to Manzini (2008).

Table 2. Solimões 541 - Sustainability characteristics

\begin{tabular}{|c|l|}
\hline $\begin{array}{c}\text { Dimension of } \\
\text { Sustainability }\end{array}$ & \multicolumn{1}{c|}{ Characteristics } \\
\hline \multirow{5}{*}{ Environmental } & $\begin{array}{l}\text { - full occupation of a big place } \\
\text { (collective use) } \\
\text { - engagement of the users in place } \\
\text { conservation } \\
\text { - multifunctional furniture and spaces } \\
\text { (allowing a more constant use and } \\
\text { dispensing the need of different furniture } \\
\text { for different activities) }\end{array}$ \\
\hline Social & $\begin{array}{l}\text { - regeneration of the social tissue } \\
\text { encouraging collaboration } \\
\text { - enabling peer interaction }\end{array}$ \\
\hline \multirow{5}{*}{ Economic } & $\begin{array}{l}\text { - maintenance and conservation of the } \\
\text { place by the users } \\
\text { - conscious use of resources in a shared } \\
\text { space } \\
\text { - cost share and reduction for all the } \\
\text { users (basic services like internet, water, } \\
\text { light, rent etc.) }\end{array}$ \\
\hline
\end{tabular}

Font: The authors (adapted from MEPSS, 2015).

Before leaving the place the picture check list (DESIS, 2015) was covered up. The photos taken allowed the creation of a new moodboad (Figure 2) and to fill out the In-depth format VisualisationTemplate through which all the functions and spaces were properly registered, later identified and presented. The images are the central explanation elements (Figure 3 ) at this step.

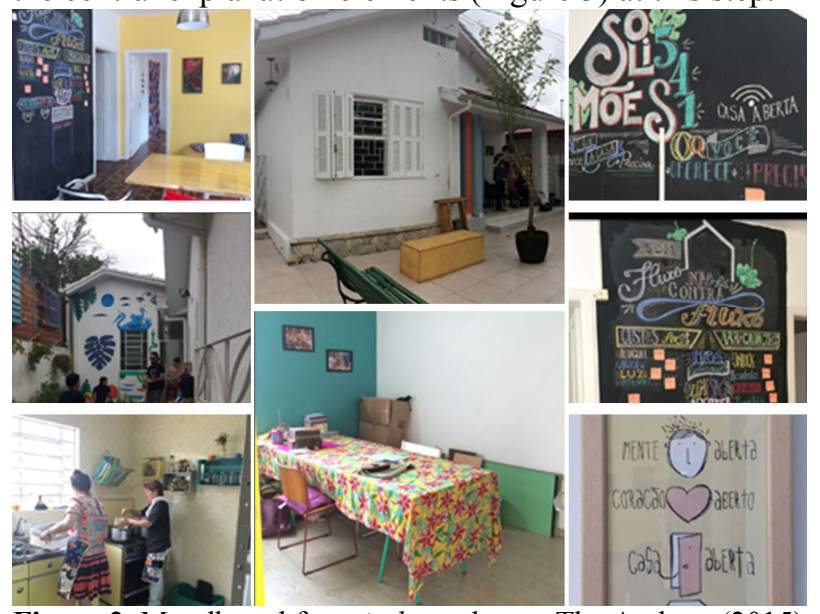

Figure 2. Moodboard from in loco photos. The Authors (2015)

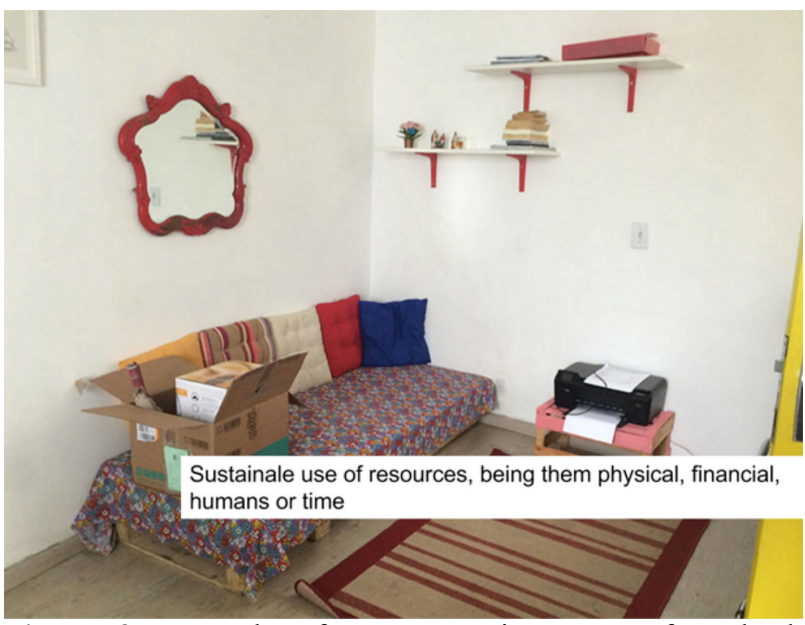

Figure 3. Example of a presentation page of In-depth format_VisualisationTemplate. The Authors (2015)

The templates of detailed analysis provided by DESIS (2015) and used on this article allowed the data distribution to validate the case as a social innovation initiative, according to Manzini (2008), which is showed in analyses and discussion section.

\section{Analyses and Discussion}

Based on the theories presented in this article, the initiative studied has both coworking spaces characteristics according to Leforestier (2009), Moriset (2014) e Merkel (2015), as well as social innovation ones, consistent with Manzini (2008). It is also possible to realize valorisation of the community, collective and collaborative senses (SCHUMACHER, 1981; ZAOUAL, 2006).

The following coworking spaces characteristics, by Leforestier (2009); Moriset (2014) e Merkel (2015), existed in Solimões 541:

1) It is in an urban context;

2) Openess - transparency and openness of spaces and ideas were key values;

3) Collaboration - meeting and collaboration among various people from different fields;

4) Accessibility - an effort to welcome many different ideas and people (physically and financially);

5) Community - growing and mutual support

6) Sustainability - conscious and optimal use of spaces and objects.

Checking the social innovation characteristics of the promising, from Manzini (2008)'s and DESIS (2015)' framework, all the questions were answered yes, which validated the initiative as a social innovation case, as it follows:

1) Is it a new way to organise daily life activities? Yes, Solimões 541 offered, similarly to some coworking spaces, a new way of organizing work and entertainment.

2) Are their social benefits? - Yes, among them it is the regeneration of a positive relationship between work and worker, respecting, according Schumacher (1981) 
the triple helix of work by having meaning, collaboration and creating and offering conditions to a decent life.

3) Are their environmental benefits? - Yes, offering the conscious use of resources as the good use of physical space and being the users the ones accountable for its maintenance.

4) Is it possible to reproduce this initiative in another context? - Yes, the case studied in this article is already a replication of an initiative from São Paulo. This replication has to respect the local contexts in order to avoid what Zaoual (2006) calls the "top-down solution transplant".

Besides the social innovation elements mentioned, it is possible to emphasize the existence of entertainment space along with workspace, which meets Schumacher (1981) theory about well being.

\section{Conclusion}

The emergence and development of coworking spaces happened due to the need of work reorganisation caused by the global crises and changes in economical and creative scenarios, especially in the big cities. Automanaged and auto-funded spaces, like Solimões 541, are also part of the shared economy; from which social innovation embrace some concepts.

The present article defined concepts of coworking spaces and social innovation and, using the DESIS (2015) protocol and a case study method, checked if the promising social innovation case, Solimões 541, identified in Curitiba-PR (Brazil) met the requirements by Manzini (2008). There is offering a new way to organise daily life activities, social and economical benefits and being replicable.

According to Yin (2010), it is not possible to generalize from a case study, once it deals with a particular situation. Although it was possible to draw a line between the definitions presented in this article, which allowed the authors to presume that coworking spaces, at large, have potential to be considered promising social innovation cases.

For a better scenario comprehension, it is necessary to conduct more case studies in other coworking spaces, having similar or different characteristics from the one of this article. These studies will allow the comparison between the cases and the raise of new research questions and hypothesis, as well as to point to new research directions.

\section{Acknowledgments}

The authors acknowledge the founder and manager of Solimões 541, which during the one-year and half the place were operating kept a very good and open environment. The place was shut down on August $16^{\text {th }}$ 2016 mainly due to difficulties in self-funding.

\section{References}

DESIS Network. Design for Social Innovation and Sustainability Network. Available in: http://www.desisnetwork.org/desis-vision. Acesso em 10.10.2015.

GANDINI, Alessandro. The rise of coworking spaces: A literature review. Ephemera: theory and politics in urban organizations. 2015 V. 15 (1), p.193-205.

FERGUSON, Francesca (ed.). Make_shift city: Renegotiating the urban commons. Berlim: Jovis, 2014. HALL, Stuart. A identidade cultural na pósmodernidade. Rio de Janeiro: DP\&A, 2006.

HOSPERS, Gert-Jan. Creative cities: Breeding places in the knowledge economy. Knowledge, Technology \& Policy. Journal Article, 2003 V. 16 (3) P.143-162

JOHNSON, Steve. Where Good Ideas Come From: the natural history of innovation. Riverhead Books, 2011

KOTZ, David M. The Financial and Economic Crisis of 2008: A Systemic Crisis of Neoliberal Capitalism. Review of Radical Political Economics September 2009 vol. 41 no. 3 305-317

LEFORESTIER, Anne. The Co-working space concept: CINE Term Project. Indian Institute of Management. Available in: http://www.iimahd.ernet.in/users/anilg/ files/Articles/Co-working\%20space.pdf $>$. Acesso em: 20.08.2015

MARZANO, Fabio Mendes. Politicas de Inovação no Brasil e nos Estados Unidos. Brasília: Fundação Alexandre de Gusmão, 2011 - Available in: $<$ http://funag.gov.br/loja/download/831-PolIticas_de_ Inovacao_no_Brasil_e_nos_Estados_Unidos.pdf $>$. Acesso em: $\overline{04} / 08 / 201 \overline{5}$

MANZINI, Ezio. Design para a inovação social e sustentabilidade: comunidades criativas, organizações colaborativas e novas redes projetuais. Rio de Janeiro: E-papers, 2008.

MERKEL, Janet. Coworking in the City. Ephemera: theory \& politics in organization. v.15 (1) p.121-139, 2015. Available in: <http://www.ephemerajournal.org/ contribution/coworking-city>. Acesso em: 20/08/2015 MILES, M. B.; HUBERMAN, A. M. \& SALDAÑA, J. Qualitative data analysis: a methods sourcebook. London: Sage Publications, 2014.

MORISET, Bruno. Building new places of the creative economy: the rise of coworking spaces. 2nd Geography of Innovation International Conference 2014.

OCDE - Organização para a Cooperação e Desenvolvimento Econômico. Manual de Oslo: Diretrizes para Coleta e Interpretação de Dados Sobre Inovação. 3a. Ed.: Paris, 2005

ONU - Organização das Nações Unidas. World's population increasingly urban with more than half living in urban áreas. 10 July 2014, New York - Available in: http://www.un.org/en/development/desa/news/populatio $\mathrm{n}$ /world-urbanization-prospects-2014.html Acesso em: 05/08/2015

SCHATZKI, T.R., K. Knorr-Cetina and E. von Savigny. The practice turn in contemporary theory. London, New York: Routledge, 2001. 
SCHUMACHER, Ernst Friedrich. O negócio é ser pequeno: Um estudo de economia que leva em conta as pessoas. Rio de Janeiro: Zahar, 1981.

SCOTT, A.J. (2006) Creative cities: Conceptual issues and policy questions, Journal of urban affairs, V 28: 117.

YIN, Robert K. Estudo de Caso: Planejamento e Métodos. $4^{\mathrm{a}}$ Edição. Porto Alegre: Bookman, 2010.

ZAOUAL, Hassan. Nova economia das iniciativas locais: uma introdução ao pensamento pós-global. Rio de Janeiro: DP\&A, 2006. 